\title{
An Analysis on the Gardens Reflecting Democratic Revolution in the Republic of China
}

\author{
Xiaohui Zhang \\ Huanghe Science and Technology College \\ Zhengzhou, China \\ e-mail: 274982665@qq.com
}

\begin{abstract}
Gardens concentrically demonstrated Chinese traditional arts, up to the Republic of China (1912-1949), because of continuous wars and warlord regime, many traditional gardens are damaged. But the upsurge of democratic revolutions drove the establishment of public gardens objectively, highlighted its function as a place for public meeting and public leisure, it also had a social function to memory. In addition, warlord and bureaucrat built private gardens to show off their status and how much money they own. Together with the running wine shops, the gardens become social custom of the Republic of China (1912-1949) and one bright landscape of the development of gardens art.
\end{abstract}

Keywords-garden; social custom of the Republic of China; democratic revolution; privation of warlord and bureaucrat

\section{INTRODUCTION}

From the late Qing dynasty to the Republic of China (1912-1949), turbulent social environment and democratic revolution drove Chinese garden to be popular and folk, made gardens that enjoyed privately by royal people go to common life, become one of the public leisure places for common people, which drove the development of new Chinese gardens and created conditions for the restore of the traditional gardens. Local warlords of that time built public gardens and private gardens competitively, so gardens of that time always have the characteristics of soldiers and warlords.

\section{AFFORESTATION TO COMMEMORATE DEMOCRATIC ReVolution, Public GARDENS NAMEd AFTER YAT-SEN}

Sun Yat-sen was the forerunner of Chinese democratic revolutions, when he put forth the Three People's Principles (Nationalism, Democracy, the People's Livelihood) and new three principles of the people, constructors of the Chinese gardens regarded the theory as the guild-line, constructed and restored gardens vigorously [1]. Public gardens emerged late in China, they begun to build with the participation of foreigners and few Chinese and presented to common people at late Qing dynasty. However, because the constructors had no power, building gardens was at most a tendency at that time, the number and scale of gardens were small, their art theory and aesthetic taste were totally different from the reality of Chinese society, so common people were indifferent to this. Till to the Republic of China (1912-1949), it was Sun Yat-sen indeed that promoted the development of public gardens. He came up with the Three People's Principles (Nationalism, Democracy, the People's Livelihood) respectively in 1905 and 1924 and new three principles of the people, both of the two involved citizen livelihood issues in detail. While the public gardens, served to improve people's life quality in nature, embodied the equality of all people and public owned in form. So Sun Yat-sen vigorously promoted the development of public gardens at spare time, and made it a public place for people to assembly and celebration.

The influence of democratic revolution promoted the construction of public gardens to some extent in Guangdong Province, in1912, Sun Yat-sen advocated to plant trees in Guangzhou and led revolutionists to plant four masson pines at Huang Huagang and one of them was still alive. Later, he established Tree-planting Day on Tomb-sweeping Day and planted trees to mourn for martyrs. On the Tree-planting Day of 1918, Sun Yat-sen personally went to Guangzhou to plant trees and decided to build the first real public garden in Guangzhou by the government of the Republic of China (1912-1949), which was the prototype of Guangzhou central park. From 1919 to 1922, Xu Shichang, then president of the Republic of China (1912-1949), went there to plant trees in 3 consecutive years, inheriting garden concept of Sun Yat-sen.

Starting from Guangdong province, all of the nations began to build public gardens. These gardens became main places for government of the Republic of China (1912-1949) to organize public activities and assembly. Take February of 1924 for example, Sun Yat-sen led people from all walks of life to offer sacrifice to Lenin in public garden in Guangzhou, October of the year, revolutionary masses of Guangdong Province held oath-taking rally at the same place to condemn Chen Lianbo for his rebellion. The assembly was held at Yuexiu Park when Sun Yat-sen declared him Extraodinary President. In 1922, Chen Jiongming betrayed democratic revolution and ordered to bombard Yuexiu building in Yuexiu Park with attempt to murder Sun Yat-sen and his wife. Yuexiu building was destroyed, fortunately, the couples were saved. So Yuexiu park witnessed the important historical event[2]. Yat-sen park, lied in Shaoguan, was the place where Sun Yat-sen held oath-taking rally and where he decided to expedited north, Hebei park, lied in Tianjin city, was the place where Sun yat-sen gave revolutionary speech, the Westlake park,lied in Chaozhou city, was the place 
where Zhou Enlai commanded the Chaoshan uprising. In addition, on his deathbed, Sun Yet-sen lived in a Line pavilion at Di'anmen in Beijing, where once was the residence of $\mathrm{Gu}$ Weijun, a famous diplomatist of the Republic of China (1912-1949), there were rare stones and dense bamboos in the yard, elegant and unique, their fragrance companied Sun Yat-sen at last moment of his life.

The death of Sun Yat-sen was a great loss to Chinese democratic revolution, in order to memorate his meritorious military service, established gardens in various regions changed names to Yat-sen park, such as Beijing, Wuhan, Shanghai, Qingpu, Jlangyin, Taizhou, Tianjin. While gardens that were establishing named Yat-sen directly, such as Shantou, Zhangzhou, Xiamen, Huizhou, Foshan, Beihai, hangzhou, Longzhou. Regions did not plan to build gardens organized specially to build gardens when the local government knew his death.

\section{UNFILLED CORNER OF PAVILIONS MEANS WORRYING COMPATRIOTS, INHERITING TRADITIONS MEANS INTEGRATION OF CHINESE AND WESTERN}

Most of the public gardens of the Republic of China(1912-1949)were built in 26 years from Xinhai revolution in 1911 to the outburst of Anti-Japanese War in 1931, especially before the "9.18" Incident in 1931, Nationalist Government paid much attention to buiold public gardens. However, after the incident, Jiang Jieshi pursued nonresistance policy, which infuriated the public and motivated their anti-Japanese enthusiasm in turn. The lost of three provinces in the northeast of China (Jilin, Liaoning and Hei Longjiang) and the enthusiasm of national anti-Japanese influenced the construction of public gardens and the creation of landscapes, reflecting the troubled times of the society from one side, even the failure of the war. Because of the Songhu Tingzhan Xieding(meaning truce between two parties), Japanese army occupied time-honored $\mathrm{Gu}$ Qi Garden and ransacked there, burned most buildings of the garden. After their temporary retreat, local masses in Nanxiang town raised funds to rebuild $\mathrm{Gu}$ Qi Garden. Constructors designed a Square pavilion on the Bamboo mountain, the former site of Gu Qi Garden, cut off one corner of the pavilion deliberately and named Buque(means mending loss) pavilion to imply current condition of the nation[3]. The absent corner happened to orient to north east, so some people thought that the designers intent to commemorate compatriots of three provinces in the northeast of China (Jilin, Liaoning and Hei Longjiang) by this.

Many gardens and their buildings were memorials of noted wars of the Republic of China(1912-1949).Huang Huagang seventy-two martyrs cemetery, The Wuchang uprising monument, Guangzhou Martyr Memorial Park, Xinhai revolution martyrs cemetery for the first revolt all witnessed the efforts of democratic revolution martyrs to overturn feudalism and build republicanism. Besides commemoration of martyrs, there also existed gardens to memorate warlords. Such as Yangzhou warlord Xu Baoshan, he cared masses and did practical things for them, so they built $\mathrm{Xu}$ garden to memorate him. The garden was designed by Yang Bingyan (Yangzhou person) and originally located in peach blossom park of Han garden, then became a garden within Slender West Lake. There were kinds of lotus ponds and pavilions, terraces and open halls, covered about 10 mu(a unit of area). Though was it to commemorate warlords, it opened to public after establishment, this was one characteristic of the running and development of gardens of the Republic of China (1912-1949). E.g. in 1914, the Summer Palace in Beijing was open to public and Show the world how corrupt and extravagant the government in the late Qing dynasty who brought calamity to the country and the people; and in 1918, the Temple of Heaven in Beijing was open to public and renamed temple of heaven park, changing a forbidden area of royal worship in Qing dynasty to a public place for entertainment for people in Beijing. From 1922 to 1928 , parks successively opened to public and renamed were Beihai Park, Drum tower park, Ancestral temple peace park, Jingzhao park in earth temple, Jingshan Park, park south of the city in altar of the god of agriculture, etc.

In terms of design style of gardens of the republic of China (1912-1949), gardens in northern China inherited tradition while gardens in southern China integrated Chinese and western countries. As what was mentioned before, most public gardens north came from old gardens, such as Jingshan Park, the Summer Palace, Beihai Park etc. They kept styles of traditional Chinese gardens and lightly influenced by the west garden art. But in southern China, newly built gardens fused the virtues of ancient and modern, Chinese and foreign, was an integration of China and west. Sikkim garden fused styles of China and Japan; Longyan Zhongshan Park combined Chinese style with Greece and Russia; Suzhou Huang Feiji Park integrated Chinese style and French style together; Shanghai Renaissance Island Park mixed western styles with Japanese style. Integrated characteristics of these gardens were the central flower bed, lawn, Statues and fountains of Occidentalism and Chinese lotus pond, winding, rockery, and flower beds [4]. They brought out the best in each other and supplement each other, without the feeling of mixture.

\section{WARLORD AND BUREAUCRAT BUILDING GARDENS EXTRAVAGANTLY, GARDEN WINESHOPS RUNNING FLOURISHINGLY}

Apart from the public gardens, the private gardens were also one demonstration of gardens of the Republic of China (1912-1949). Construction of private gardens of that time related closely to warlords involved in wars. Almost every warlord preferred to build private gardens in his district to show off his power and financial resources. In Beijing, there were more than 100 private gardens when flourishing. After the victory of democratic revolution led by Sun Yat-sen, Yuan Shikai arrogated the generalissimo of the Republic of China(1912-1949)and lived in Zhongnanhai Compound (residence of Chinese leaders), he changed Zhongnanhai Compound and nearby the Forbidden City to his private gardens attempting to have been emperor for 83 days, the other Presidents of the republic of China(1912-1949) also built private gardens in Beijing, such as Wangfujing home 
garden of Li Yuanhong, TongFu home garden of Caokun and Jiantao gaden of Xu Shichang.

Caokun, the leader of Chihli clique, once was three straight Lu Yu XunYue Shi (an official position) of late Qing dynasty, with a high position, he guarded Beijing portal and was very influential in Zhili area (mainly today's Hebei province). His mansion was originally in Baoding, Hebei province, to show his mingle with men of letters and pose as a lover of culture, he once sent servants to steal white jade in the Old Summer Palace blatantly and shipped to Baoding to build private garden. After he became the generalissimo, his subordinates such as Wang Huaiqing, Che Qingyun and Wang Lanting followed his example, using the defensible power building many private gardens in Beijing. Among the atmosphere that senior officials building private gardens, Prime Minister Tang Shaoyi was a "triton of the minnows", he took the advantages of position and built a private garden covered about 30 hectares in hometown Zhuhai city, the biggest private garden of gardens belonging to bureaucrats of the republic of China (1912-1949) excluding generalissimo. When building was finished, he named the garden "Linglong Shan Guan (means Exquisite Yamadate) in person. "Linglong" showed its unique, "Shan" embodied its southern style and wide area, while, "Guan" proved it was private. At the end of 1912, as a cabinet minister Tang Shaoyi renamed "Linglong Shan Guan" the "paradise" to show the wish having fun with the citizens. Although it had a name that similar to a public garden, during the reign of Tang Shaoyi, it did not open to public, just using it to befog the minds of the people.

In 1930s, Huang Jinrong, leader of mobdom, owned the biggest private garden in Shanghai, the garden covered more than $60 \mathrm{mu}$, Zhuyue pavilion, Lingyun pavilion, Sijiao Pavilion (four-corner pavilion) and Kuanyin Pavilion were boutiques of the garden. In addition, Huang Jinrong specially bought rare stones from famous Yan Family's Garden in Suzhou to build his garden and the degree of luxury was breathtaking. Merchant princes in Shanghai, Jiangsu and Zhejiang were main builders of private gardens. In Yangzhou, Pawnbroking businessman Huang Yizhi built Yilu garden, Zhou Jingchen, made his fortune from salt trade, built Ping garden, Lu Dianhu, a re-seller of scarce goods, built Paolu garden. In Wuxi, businessman Wang Yuqing and Rong Zongjing built plum garden and Jianli garden known far and wide respectively. In Suzhou, overseas Chinese businessman Du Qisun built Qi garden, the first choice for merchant princes to gathering. These princes spent a large amount of money to build extremely extravagant private gardens, making them the representatives of the highest level of private gardens of the Republic of China (1912-1949) objectively.

Besides northern warlords and southern princes, some of the literati built their private gardens during 1912-1949. Liang Qichao built a small garden in his residence at 44th lane of eastern Beijing, The representative of the Lingnan School characters Chen Shuren built $\mathrm{Chu}$ garden and $\mathrm{Xi}$ garden at home. The three private gardens were built by literati of the Republic of China (1912-1949) at their own expense and they were representative works. To most poor literati of troubled times, they could hardly make their own living, let alone build private gardens. What was worth mentioning was that whatever warlords, merchant prince and literati, most of them built private gardens for showing off and enjoying, only a little of gardens were built for running [5]. Such as garden wine shops arisen in Guangzhou, they combined garden art with hotel management, and were quite popular with the market. Panxi Wineshop, Da Sanyuan Wineshop, west garden wine shop, literal garden wine shop and south garden wine shop, were all changed from private gardens and were known in Guangzhou, some of these old brands still exist today. Because of appreciate management, they increasingly appeal customers, newly built wine shops emerged in places of the nation, becoming one bright scene of garden art development of the Republic of China (19121949).

\section{CONCLUSION}

Whether public gardens oriented national fashion or private gardens paid attention to enjoy luxury, they are all the progress of Royal Garden popularization to a certain extent, gardens are gradually not enjoyed only by royal people, becoming an entertainment place for a majority of people in sorts of attitude and appearance. The gardens of the Republic of China (1912-1949) enrich Chinese gardens with compatibility and open-minded personality at the change of history and become important transitional representatives of the popularization of gardens.

\section{REFERENCES}

[1] Zhu Junzhen. The History of Chinese Modern Landscape[M]. Beijing: China Building Industry Press,2012:118-120.

[2] Zhou Linjie. The History of Guangdong Modern Landscape[M]. Beijing: China Building Industry Press, 2011:46-47.

[3] Lv Mingwei. Classical Chinese Garden[M].Mount Huangshan: Huangshan Publishing House, 2011:93-95.

[4] Cao Lindi. Introduction to Chinese Garden art[M].Beijing: China Building Industry Press,2009:147-148.

[5] Wangyi. Heart of Chinese Garden[M]. Beijing: Peking University Press, 2014:30-32. 